\title{
How Selected Macroeconomic Factors Affect the Corporate Profitability of Transportation and Storage Companies in Selected European Economies
}

Jak vybrané makroekonomické faktory ovlivinují podnikovou ziskovost společností z odvětví Doprava a skladování ve vybraných evropských ekonomikách

\author{
PETRA RŮČKOVÁ \\ NICOLE ŠKULÁŇOVÁ
}

\begin{abstract}
The goal of most companies is to make a certain amount of profit, to which all-important business decisions are a subject. The importance of this goal is evidenced by the fact that profitability indicators belong to the key indicators of business success. Unfortunately, profitability is affected by many often-unpredictable factors, which usually come from the external environment of the company. In this research, these factors are represented by GDP growth rate, inflation rate, reference interest rate, unemployment rate, gross fixed capital formation and the exchange rate against the euro. The aim of the research is to find out whether selected factors influence the company's profitability or not. Companies of the transportation and storage industry coming from eight selected economies of Central and Eastern Europe are the subject of the analysis. The industry will be analysed at the level of fifteen sub-industries using the Generalized Method of Moment. The data cover the period 2010-2018 and provide information on approximately 25,000 companies. The size of the sample does not allow the results to be summarized in one sentence, but they showed that companies in the selected industry are for the most part negatively affected by the reference interest rate of the economy.
\end{abstract}

\section{Keywords}

corporate profitability, exchange rate, GDP growth rate, gross fixed capital formation, inflation rate, reference interest rate, unemployment rate

\section{JEL Codes}

G30, G32

\section{DOI}

http://dx.doi.org/10.37355/acta-2021/2-03 


\begin{abstract}
Abstrakt
Cílem většiny podniků je dosahovat určité výše zisku, čemuž se podřizují snad všechna důležitá obchodní rozhodnutí. O významnosti tohoto cíle svědčí fakt, že ukazatele rentability jsou řazeny mezi klíčové indikátory podnikatelské úspěšnosti. Bohužel na ziskovost má vliv spousta mnohdy nepředvídatelných faktorů, které obvykle pocházejí z vnějšího okolí podniku. V tomto výzkumu jsou tyto faktory zastoupeny tempem růstu HDP, mírou inflace, referenční úrokovou sazbou, mírou nezaměstnanosti, tvorbou hrubého fixního kapitálu a měnovým kurzem k euru. Cílem výzkumu je zjistit, zda vybrané faktory ovlivňují podnikovou rentabilitu či nikoliv. Předmětem analýzy jsou podniky z odvětví Doprava a skladování pocházející z osmi vybraných ekonomik střední a východní Evropy. Odvětví bude analyzováno na úrovni patnácti pododvětví za použití zobecněné metody momentů. Data pokrývají období 2010-2018 a podávají informace o zhruba 25000 podnicích. Rozsáhlost vzorku neumožňuje shrnout výsledky v jedné větě, avšak výsledky poukázaly na to, že podniky z vybraného odvětví jsou z velké části nejvíce ovlivněny negativně referenční úrokovou sazbou ekonomiky.
\end{abstract}

\title{
Klíčová slova
}

měnový kurz, míra inflace, míra nezaměstnanosti, podniková rentabilita, referenční úroková sazba, tempo růstu HDP, tvorba hrubého fixního kapitálu

\section{Introduction}

Profitability is a key characteristic of every business unit (except for non-profit companies), as profit generation allows a company to operate, expand and renew. This is a very important variable from the point of economic theories view. One of the basic theories being known by all economists the "profit maximization rule" is, which is associated with neoclassical economics. The profit also forms one of the investment triangle vertices, which is an important part of corporate finance theory.

We can measure profitability in different ways. The most common ones the ratios are, which measure various items in the balance sheet and profit and loss statement. As the subsequent literature review shows, ROA, ROE, ROAA, ROAE and net interest margin are the most common indicators. However, the research deals with companies being different from the literature review; it mainly includes companies of the banking and tourism industry and therefore, it is not appropriate to use all indicators mentioned in these reviews. The ROA, ROE and ROS indicators were selected for this research, as they gradually show how efficiently the assets are used, how the capital invested by investors is valued and what part of the revenues falls into the profit.

Everything in a business is affected by many factors. The first group includes factors that come from the internal environment of the company. These factors can be influenced and anticipated by the company. The second group includes factors coming from the external environment of the company. These factors are very unpredictable and cannot be influenced by the company. This research focuses on this group of factors. Specifically, there are six selected macroeconomic factors - the rate of GDP growth, the inflation rate, 
the reference interest rate, the unemployment rate, gross fixed capital formation and the exchange rate against the euro.

The aim of the research is to find out whether selected factors influence the company's profitability. Within the target, a positive impact of economic development, gross fixed capital formation and the inflation rate at the level of profitability is expected. The reference interest rate and the unemployment rate should have a negative effect on the profitability level. There are no prerequisites for the exchange rate. Companies of the transportation and storage industry originating from eight selected economies of Central and Eastern Europe are the subject of the analysis. Specifically, these are the Czech Republic, Slovakia, Poland, Hungary, Austria, Slovenia, Bulgaria and Romania.

A dissemination of existing knowledge on the effects on corporate profitability should become the main benefit of this research as not many studies were provided dealing with industries other than banking and tourism. Also, current researches do not contain all six selected factors, so there should be an expansion of knowledge in terms of these factors and, last but not least, in terms of selected economies. Furthermore, all enterprises that had the relevant database available for the given economies, industries and periods are analysed. It should be noted that the results of the studies strongly depend on geographical, size and sectoral affiliation. At the same time, the size of the examined sample is also important, whether we analyse all companies from a database, or only, for example, the twenty largest companies in the industry, etc. In other economies, industries and examined sample of companies, the results may be different. In total, about 25,000 companies are analysed. Detailed analyses could become a benefit because the said industry is examined by fifteen subindustries individually and the factors' impact on profitability are then better readable than if the industry would be analysed as a whole.

This research is organized as follows. Section 1 outlines earlier studies on the factors of the corporate profitability. Section 2 presents the research methodology, variables and provides a description of the industry and examined economies. Section 3 describes the results of the analysis of variable dependencies. Section 4 presents the conclusions.

\section{Literature Review}

This part contains a summary of found studies in the field of corporate profitability and their determinants. The vast majority of these studies focus on corporate profitability in the banking and tourism industries. However, even though they are not in line with our chosen industry, some evidence is needed to create the expected impacts of selected determinants at the level of profitability.

Out of the twenty-nine studies found, the following twenty-eight studies examined the impact of economic development on profitability: Bourke (1989) for 90 banks from Europe, the US and Australia, Molyneux and Thornton (1992) for 18 European countries, Claessens, Demirgüç-Kunt and Huizinga (1998) for 80 countries, Demirgüç-Kunt and Huizinga (1998) for 29 countries, Bikker and Hu (2002) for 26 OECD countries, Bashir (2003) for 21 Islamic countries, 
Athanasoglou, Brissimis and Delis (2008) for Greek banks, Albertazii and Gambacorta (2009) for countries from Euro area and Anglo-Saxon countries, Flamini, McDonald and Schumacher (2009) for 216 commercial banks from 42 countries in Sub-Saharan Africa, Aliaga-Diaz and Olivero (2010) for the US, Pervan, Pervan and Guadagnino (2010) for Croatina commercial banks, Dietrich and Wanzenried (2011) for 372 Swiss commercial banks, Curak, Poposki and Pepur (2012) for 16 Macedonian banks, Tan and Floros (2012) for 101 Chinese banks, Akotey, Sackey and Amoah (2013) for 17 life insurance firms from Ghana, Gaganis, Hasan and Pasiouras (2013) for 399 listed insurance firms from 52 countries, Košak and Čok (2013) for Croatian, Bulgarian, Romanian, Serbian, Macedonian and Albanian banks, Mirzaei, Moore and Liu (2013) for 308 banks from emerging economies and 1,621 banks from advanced economies, Dietrich and Wanzenried (2014) for 10,165 commercial banks from 118 countries, Almeida and Divino (2015) for 64 Brazilian banks, Djalilov and Piesse (2016) for 275 commercial banks from early and late transition countries, Saona (2016) for 7 Latin America counries, Zuidberg (2017) for 125 airports from Europe, the US, Canada, Australia and New Zealand, Chouikh and Blagui (2017) for ten Tunisian listed banks, Martins, Serra and Stevenson (2019) for 108 real estate banks from the US, the UK and Germany, Vera-Gilves et al. (2020) for 23 Ecuadorian private banks, Le and Ngo (2020) for 23 countries, Killins (2020) for 38 federally regulated domestic life insurers.

We can see that the authors have dealt with a number of economies. A positive impact on the level of profitability is the dominant impact. It is thus clear that the resulting impacts are more or less the same throughout the world. It can be seen that the results mostly indicate a positive impact of economic development on the level of profitability. Some explain the positive impact as saying that economic prosperity contributes to the growth of banks' economic activity. Such increase may be explained by an increase in household savings and an increase in corporate demand for credit.

For example, Athanasoglou, Brissimis and Delis (2008) have further revealed that if the output of the economy is above trend, the resulting coefficient for a given variable is doubled. Conversely, if the output of the economy is below trend, the coefficient is insignificant. It follows that Greek banks were able to isolate their performance during a period of unfavourable economic development.

Dietrich and Wanzenried (2011) and Martins, Serra and Stevenson (2019) also dealt with the banking sector and divided the period under investigation into whole, pre-crisis and crisis periods. Both studies showed the same result, namely a positive impact of economic development during the whole and pre-crisis period and a negative impact during the crisis. Based on this result, banks' profits appear to be pro-cyclical, given that demand for credit increases during economic growth. Conversely, if the economy is in recession, the credit quality of banks is deteriorating.

Other negative effects of economic development were found in the study of Tan and Floros (2012), Dietrich and Wanzenried (2014) for low-income economies, Saona (2016), Chouikh and Blagui (2017), Zuidberg (2017) for European low-cost airports, Rynair/easyJet and airports with more than 10 mil passengers, Le and Ngo (2020). It is difficult to say which economies included certain samples, however, if economies were to succeed, the negative impact could be explained by declining profitability for companies with 
increasing output, as higher operating costs could become in many cases an additional output (or maintaining the current relatively high output level). The inflation's impact on profitability was included in these studies - Bourke (1989) for 90 banks from Europe, the US and Australia, Molyneux and Thornton (1992) for 18 European countries, Claessens, Demirgüç-Kunt and Huizinga (1998) for 80 countries, Demirgüç-Kunt and Huizinga (1998) for 29 countries, Albertazii and Gambacorta (2009) for countries of the Euro area and Anglo-Saxon countries, Flamini, McDonald and Schumacher (2009) for 216 commercial banks coming from 42 countries in Sub-Saharan Africa, Dietrich and Wanzenried (2011) for 372 Swiss commercial banks, Martins, Serra and Stevenson (2019) for 108 real estate banks from the US, the UK and Germany, Vera-Gilves et al. (2020) for 23 Ecuadorian private banks, Le and $\mathrm{Ngo}$ (2020) for 23 countries. Also, in the case of the inflation rate's effect on the profitability, a positive impact was revealed in most cases. Many authors argue that the inflation's impact on profitability depends on whether inflation movement is expected. If inflation is expected to rise, banks can adjust interest rates (increase) and thus increase their yields. It is also necessary to take into account whether banks' costs are rising faster than inflation. Of course, inflation can also have a negative impact on profitability, but there are not many such studies. A negative impact was found by Martins, Serra and Stevenson (2019) during the crisis period 2007-2010, Le and Ngo (2020).

The following studies included an analysis of the interest rates' impact on profitability Bourke (1989) for 90 banks from Europe, the US and Australia, Molyneux and Thornton (1992) for 18 European countries, Claessens, Demirgüç-Kunt and Huizinga (1998) for 80 countries, Demirgüç-Kunt and Huizinga (1998) for 29 countries, Sufian ad Chong (2008) for Philippines banks, Albertazii and Gambacorta (2009) for countries of the Euro area and Anglo-Saxon countries, Mirzaei, Moore and Liu (2013) for 308 banks coming from emerging economies and 1,621 banks of advanced economies, Dietrich and Wanzenried (2014) for 10,165 commercial banks coming from 118 countries, Almeida and Divino (2015) for 64 Brazilian banks, Djalilov and Piesse (2016) for 275 commercial banks of early and late transition countries, Chouikh and Blagui (2017) for ten Tunisian listed banks, Martins, Serra and Stevenson (2019) for 108 real estate banks coming from the US, the UK and Germany, Vera-Gilves et al. (2020) for 23 Ecuadorian private banks. In the given studies, the slightly positive impact of the interest rate on the profitability prevails. The negative impact was revealed at Sufian and Chong (2008), Mirzaei, Moore and Liu (2013), Dietrich and Wanzenried (2014) for high-income economies, Djalilov and Piesse (2016) for early transition countries, Vera-Gilves et al. (2020).

Last but not least, we see that the interest rate also has a positive impact on profitability level. Studies to be reviewed selected by us did not include more determinants and therefore, the assumptions for the unemployment rate, gross fixed capital formation and the exchange rate have to be completely re-created.

\section{Data and methodology}

Companies operating in the territory of eight selected economies of Central and Eastern Europe are the subject of the research. Specifically, these are the countries of the so- 
called extended Visegrád Group, which includes the Czech Republic (CZ), Slovakia (SK), Poland (PL), Hungary (HU), Austria (AT), Slovenia (SI), Romania (RO), Bulgaria (BG). The fact that representatives of these economies very often attend basic V4 meetings and this designation is commonly used in the media in connection with these economies is the reason for Austria, Slovenia, Romania and Bulgaria to be included in this research.

The selected industry is according to the NACE classification section $\mathrm{H}$ - Transportation and Storage. This industry is divided into fifteen groups - subindustries that are the subjects of our analysis. According to the mentioned classification, these are the following groups: 491 Passenger rail transport, interurban, 492 Freight rail transport, 493 Other passenger land transport, 494 Freight transport by road and removal service, 495 Transport via pipeline, 501 Sea and coastal passenger water transport, 502 Sea and coastal freight water transport, 503 Inland passenger water transport, 504 Inland freight water transport, 511 Passenger air transport, 512 Freight air transport and space transport, 521 Warehousing and storage, 522 Support activities for transportation, 531 Postal activities under universal service obligation, 532 Other postal and courier activities. In Table 1, we can see the number of companies in individual economic and sectoral groups. It should be noted that for subindustries covering less than five companies, no analyses were performed as the method used (GMM) requires at least five companies. Of course, for the subindustry represented by only one company, the simple panel regression can be applied, but the results are not statistically significant. Furthermore, the table shows which subindustries clearly dominate - Freight transport by road and removal service, Warehousing and storage and Support activities for transportation. Freight transport by road is evident because firstly, a half of the selected economies are landlocked countries (CZ, SK, HU, AT) and secondly, the selected countries export and import mostly in Europe and therefore, the use of road transport is more advantageous and less expensive than e.g. shipping or air transport.

The industry is considered one of the most important industries in Europe, and therefore in the world, as it is present in our daily activities - tourist transport, transport to work, storage of goods or food. Given its importance, the sector deserves an attention, even though, according to the statistics, the sector accounts for only around $5 \%$ of the European Union's GDP.

With regard to the sample of companies, these are all companies that have been found in the Orbis database, which provides information on medium, large and very large companies. A total of 25,242 companies are analysed. Information based on the financial statements comes from the Orbis database, while macroeconomic data are taken out of the World Bank database (GDP, inflation, unemployment, gross fixed capital formation), the databases of individual central banks (reference interest rate) and the Investing.com database (exchange rate). The data cover the period 2010-2018. This period was chosen with regard to the time series located in the Orbis database. Unfortunately, a longer time series is not available. 
Table 1: Number of companies in individual subindustries in individual economies

\begin{tabular}{ccccccccc}
\hline & $\mathrm{CZ}$ & $\mathrm{SK}$ & $\mathrm{PL}$ & $\mathrm{HU}$ & $\mathrm{AT}$ & $\mathrm{SI}$ & $\mathrm{BG}$ & $\mathrm{RO}$ \\
\hline 491 & 9 & 2 & 16 & 2 & 12 & 1 & 19 & 6 \\
492 & 20 & 11 & 53 & 24 & 10 & 5 & 12 & 44 \\
493 & 290 & 140 & 726 & 169 & 517 & 45 & 332 & 616 \\
494 & 3,127 & 1,373 & 4,418 & 1,263 & 1,238 & 699 & 1,264 & 1,987 \\
495 & 2 & 2 & 8 & 2 & 3 & 1 & 1 & 2 \\
501 & 1 & 15 & 12 & 2 & 13 & 1 & 10 & 1 \\
502 & 1 & 21 & 37 & 1 & 2 & 9 & 13 & 9 \\
503 & 4 & 4 & 5 & 12 & 8 & 0 & 6 & 6 \\
504 & 7 & 4 & 13 & 11 & 1 & 1 & 9 & 22 \\
511 & 25 & 9 & 52 & 12 & 50 & 13 & 17 & 26 \\
512 & 2 & 3 & 15 & 8 & 7 & 0 & 16 & 10 \\
521 & 219 & 103 & 292 & 224 & 60 & 15 & 98 & 106 \\
522 & 630 & 388 & 1141 & 604 & 599 & 197 & 453 & 561 \\
531 & 1 & 1 & 2 & 1 & 4 & 2 & 13 & 2 \\
532 & 33 & 41 & 62 & 94 & 52 & 18 & 94 & 135 \\
\hline$\Sigma$ & 4,371 & 2,117 & 6,852 & 2,429 & 2,576 & 1,007 & 2,357 & 3,533 \\
\hline
\end{tabular}

Source: Author's own calculations based on data from Orbis database

The aim of the research is to find out whether selected factors influence the company's profitability. Specifically, there are six selected macroeconomic factors - the rate of GDP growth, the inflation rate, the reference interest rate, the unemployment rate, gross fixed capital formation and the exchange rate against the euro. Based on the literature review and based on our own assumptions, we expect the following relationships between determinants and profitability indicators:

- Positive relationship between the economic development and gross fixed capital formation - if the economy grow, companies usually thrive and their profits and demand for their products grow, too, as disposable income increases for all economic agents due to economic prosperity.

- Positive relationship between the profitability level and inflation rate - in this case, there is a link to the real interest rate, which decreases as the inflation rate increases resulting to companies being able to obtain a cheaper debt, which could support output growth and thus increase profits.

- Negative relationship between the profitability level and the reference interest rate - the lower the interest rates in the economy, the lower the cost of debt financing is, the use and advantage of which were mentioned in the previous point.

- Negative relationship between the profitability level and unemployment rate rising unemployment usually leads to a decline in demand for business products or services, as social benefits or unemployment benefits are not as high as wages and therefore, household disposable income is lower. 
- No assumption is made for the exchange rate. The impact of the exchange rate is analysed only for the Czech Republic, Poland, Hungary, Bulgaria and Romania, as these countries do not have the euro as their national currency. It is well known that a weaker currency stimulates exporters and a stronger currency stimulates importers. All five countries are both exporters and importers. Because it very much depends on which of the value (exports or imports) prevails during the observed period, it is not possible assume a relationship between variables.

\section{Variables}

The following subchapter describes the method used to analyse the impact of selected determinants on the companies' profitability level. The panel regression was chosen as the method using the GMM method. Within this method, we can divide the variables into endogenous and exogenous.

The left side of the equation or endogenous variable is represented by profitability indicators. The literature review showed the possibility of using several indicators, such as ROA, ROAA, ROAE, ROE, net interest margin, but given that the companies come mainly from the banking and tourism industry, not all of these indicators are suitable for all companies. Three indicators were selected with regard to the comparison on which part of corporate resources (assets, equity, sale) may have the greatest impact. The return on assets is the ratio of profit before tax and interest and total sales. Return on equity is the ratio of profit after tax and equity. Return on sales is then the share of profit before tax and interest and total sales. These are three perspectives, with the ROA indicator assessing the return on total assets invested in the company, regardless of the sources from which they are financed. The indicator is used to measure overall efficiency and de facto assesses the performance of past managers. The ROE indicator assesses the return on capital invested by shareholders or owners. It tells about the ability of management to manage their sources. At the same time, these two indicators have a certain connection between them, which is important in terms of the analysis of capital structure and financial leverage. It is true that if no debt sources and thus financial leverage are used, then the assets are financed only by own sources, and therefore the ROA and ROE indicators are equal. However, this research deals with macroeconomic effects on the level of profitability, and therefore this relationship is irrelevant. At the same time, it is not possible to determine the size of ROA and ROE for a huge number of companies, as companies are examined in panels where values are averaged and certainly at least one company will use debt sources to finance its activities, and therefore the indicators would never equal. The last indicator, the ROS indicator, tells us how many currency units of profit the company produces per currency unit of sales.

The right side of the equation or exogenous variables are represented by individual determinants. Exogenous variables are specifically in the form of the rate of GDP growth at market prices, basic interest rate of the economy (IR), inflation rate (INF), unemployment rate (UN), gross fixed capital formation (GFCF) and exchange rate to the euro. The exchange rate is included only in the analyses of the Czech, Polish, Hungarian, Bulgarian 
and Romanian companies. Austria, Slovakia and Slovenia have the euro as their national currency. The euro was chosen in view of the fact that these are European economies trading mainly in Europe and have European countries as their main trading partners.

\section{Methodology}

As indicated in the previous section, panel regression using the Generalized Method of Moments was used to analyse the dependencies between the variables. A variety of econometric methods can be used, however, as reported by Jagannathan et al. (2002), this method eliminates the shortcomings of other methods and therefore found application mainly in the financial field. Given the number of companies, economies and determinants, the use of panels is a clear choice. Unfortunately, the least squares method is not suitable due to the need for stationary time series, which macroeconomic data often may not meet. (Průcha, 2014)

The GMM method was first described by Arellano and Bond (1991), who subsequently developed it in further studies with other authors - Arellano and Bover (1995), Blundell and Bond (1998). The method has its basic characteristics, which were summarized by Roodman (2009) in his study. The author states that the method is also ideal for shorter time series; there is a linear functional relationship and fixed individual effects are present; the endogenous variable on the left side of the equation is dynamic and depends on its lagged values; on the other hand, exogenous variables may not be strictly independent, as indicated by the fact that variables may be correlated with past and present errors; the method cannot test autocorrelation and heteroscedasticity and at the same time these phenomena should not occur through observation. The method also solves the endogeneity problem, which is the correlation between the exogenous variable and the error term, which could occur in the application of the least squares method. Ullah et al. (2018) states that the solution to this problem takes place through internal tools (lagged value of endogenous variable, internal transformation processes) that remove unobserved heterogeneity, simultaneity and dynamic endogeneity, which are considered sources of endogeneity.

Ullah et al. (2018) further adds that, as mentioned, since the method cannot test the presence of autocorrelation and heteroscedasticity, some tool is needed to determine whether the model and its results are credible. There are several tools. The Sargan test was chosen for this research, the final value of which must exceed 0.05 in order to make the model robust and reliable, so the model can be built correctly, which means that if we change the parameters slightly, we should get the same results.

The equation of the model looks like this:

$$
\begin{gathered}
P R O F_{i t}=\alpha_{0}+\beta_{1} * P R O F_{i t-1}+\beta_{2} * G D P_{i t}+\beta_{3} * I R_{i t}+\beta_{4} * I N F_{i t}+\beta_{5} \\
* U N_{i t}+\beta_{6} * G F C F_{i t}+\beta_{7} * E X_{i t}+\varepsilon_{0}
\end{gathered}
$$

where PROF means the gradual use of individual profitability indicators ROA, ROE, ROS. This variable indicates the profitability for the i-th number of companies in a given 
economy in a particular subindustry during the period t (2010-2018). The right side of the equation consists of individual determinants, which are described above (GDP, IR, INF, UN, GFCF, EX). At the same time, there is a constant a on this side and a random component $\varepsilon$, which contains other determinants of profitability, which are not dealt with in this research, but affect its amount. The last variable on this page mentions the lagged value of the dependent variable several times. This is an annual lag.

\section{Results and discussion}

Tables 2, 3 and 4 show the results of the GMM method for three profitability indicators, individual subindustries and individual economies. Given that research focused on eight selected economies, we see that, with a few exceptions, most subindustries do not include results for all economies. The reason is that the models for the given economies did not meet the assumptions of the Sargan test (its values were lower than 0.05) and the model is not robust and the results are not reliable.

In Tables we can see the abbreviation "cor" with the abbreviations of individual determinants in some columns. This abbreviation means that a given time series (a given determinant) shows a high value of the correlation coefficient with another time series, and therefore there is no value of the coefficient for GMM model.

The first column includes a variable we did not select but it is an automatic part of each model; this variable also helps to solve the endogeneity problems we mentioned in the previous section. This is the lagged value of profitability indicators. All three profitability indicators are dominated by the positive impact i.e. if companies achieved a certain level of profitability in the past, they would continue in this trend in the future. However, the coefficients in all cases are very low (tenths, hundredths or thousandths), so we cannot talk about a significant impact of the variable on the profitability level. It is rather direction the profitability could take in the case a given coefficient reaches the larger values.

Another variable that can be mentioned before a more detailed analysis of the results, a gross fixed capital formation is. As with the lagged value of the profitability indicators, the coefficients for this variable are indeed very low; lower than in the previous case. The values reach certain numbers, which are multiplied by ten to minus the eighth and beyond. In this case, it is really a rough indication of the direction, in which this variable could affect the level of profitability. For the ROE and ROS indicators, no indication prevails; for the ROA indicator, the negative impact slightly outweighs the positive one. Gross fixed capital formation is linked to the economic and investment cycle. In terms of the positive impact, if companies created value in the previous period, they would continue to do so in the following period. In the case of a negative impact, this does not apply, in which case companies would create value in the following period but its amount would decrease.

The impacts of the remaining variables on the profitability level are analysed for individual subindustries and individual economies within these subindustries. The results for selected profitability indicators are also compared. Comments on the results focus more 
on the variables with the greatest impact, as the analysis has shown a huge number of results that cannot be analysed in detail.

If we look at Czech companies, Table 1 showed that Czech companies are not represented in certain industries. No results for these companies can be found in subindustries 495, 501, 502, 503, 512 and 531. The remaining subindustries have a result for at least one profitability indicator. Overall, inflation and the unemployment rate have the greatest impact on the profitability level followed by the reference interest rate and economic development. Considering the return on assets of subindustries 491, 492, 494, 532, the unemployment rate has the greatest impact on it whether negative or positive. For subindustries 493, 504, 511 and 521, the inflation rate has the greatest positive impact. The impact of the inflation rate on the appreciation rate of the company's assets can be justified by the fact that in the Czech Republic, the average inflation rate was $1.6 \%$ within the period under review, which may have reduced the real expression of interest rates; those may have become lower thus companies could acquire additional assets, by them increase the production and thus their profitability. The negative impact of the unemployment rate is obvious, as during the period under review this rate fell from 7.3 to $2.2 \%$ in the Czech economy. The increase in the employed population meant an increase in the disposable income that could be spent on products in the given subindustries. The positive impact of the unemployment rate is strange and difficult to explain. Return on equity is affected by the reference interest rate $(491,532)$, the unemployment rate $(492,504)$ and economic development $(511,522)$. The negative impact of the interest rate meant cheaper debt financing costs. On average, the reference interest rate was $0.4 \%$. If we add the mentioned rate of inflation, it was not expensive to get the other sources the owners could invest in the business and thus increase the production. The negative impact of the unemployment rate and the positive impact of economic development meant the same thing, namely an increase in disposable income that could be put into business. The level of the return on sales was affected by the inflation rate $(491,532)$ and the interest rate $(492,504,511)$. The negative impact of the reference interest rate meant cheap debt financing, by which an increase in production could be supported resulting in sales increase. This idea can be supported by the positive impact of the inflation rate explained above.

We did not find any result for Slovak companies in subindustries 491, 495, 503, 504, 512 and 531. The remaining subindustries have a result for at least one profitability indicator. Overall, the reference interest rate has the greatest impact on the profitability level, which clearly dominates in twelve out of nineteen cases. The level of return on assets is mostly affected by the reference interest rate $(492,493,501,511,521,532)$ and in the case of subindustry 502 , it is affected by the unemployment rate. The negative impact of the interest rate on the appreciation rate of the company's assets can be justified by the fact that in Slovakia the average reference interest rate was $0.3 \%$ in the period under review, which could mean very low costs when obtaining debt financing, out of which other assets can be purchased and thus the production could be increased. The negative impact of the unemployment rate is obvious, as, in the Slovak economy, during the period under review this rate fell from 14.4 to $6.5 \%$. The increase in the employed population meant an increase in the disposable income that could be spent on products in the given subindustry. The inflation rate $(492,501,502)$, the interest rate $(511)$ and the 
development of the economy (532) had an impact on the level of return on equity. The resulting impacts meet our assumptions. The Slovak economy had a very good growth rate during the period under review, which averaged $3.1 \%$. This number indicates that the companies were in a period of economic prosperity, which usually means an increase in profits and disposable income that can be invested in the business and thus they could increase their future profits. The inflation rate averaged $1.4 \%$, which reduces the real interest rate with the above-mentioned average reference interest rate. As a result, it was very cheap to obtain additional sources of financing that could be invested in equity and thus strengthen the financial background of companies. The level of return on sales was again most affected by the reference interest rate $(494,501,502,522,532)$ and the inflation rate $(511,492)$. The development of variables has already been described in the previous text. The good development of these variables could lead to an increase in assets, equity and sales through debt financing.

Table 2: GMM results for ROA indicator

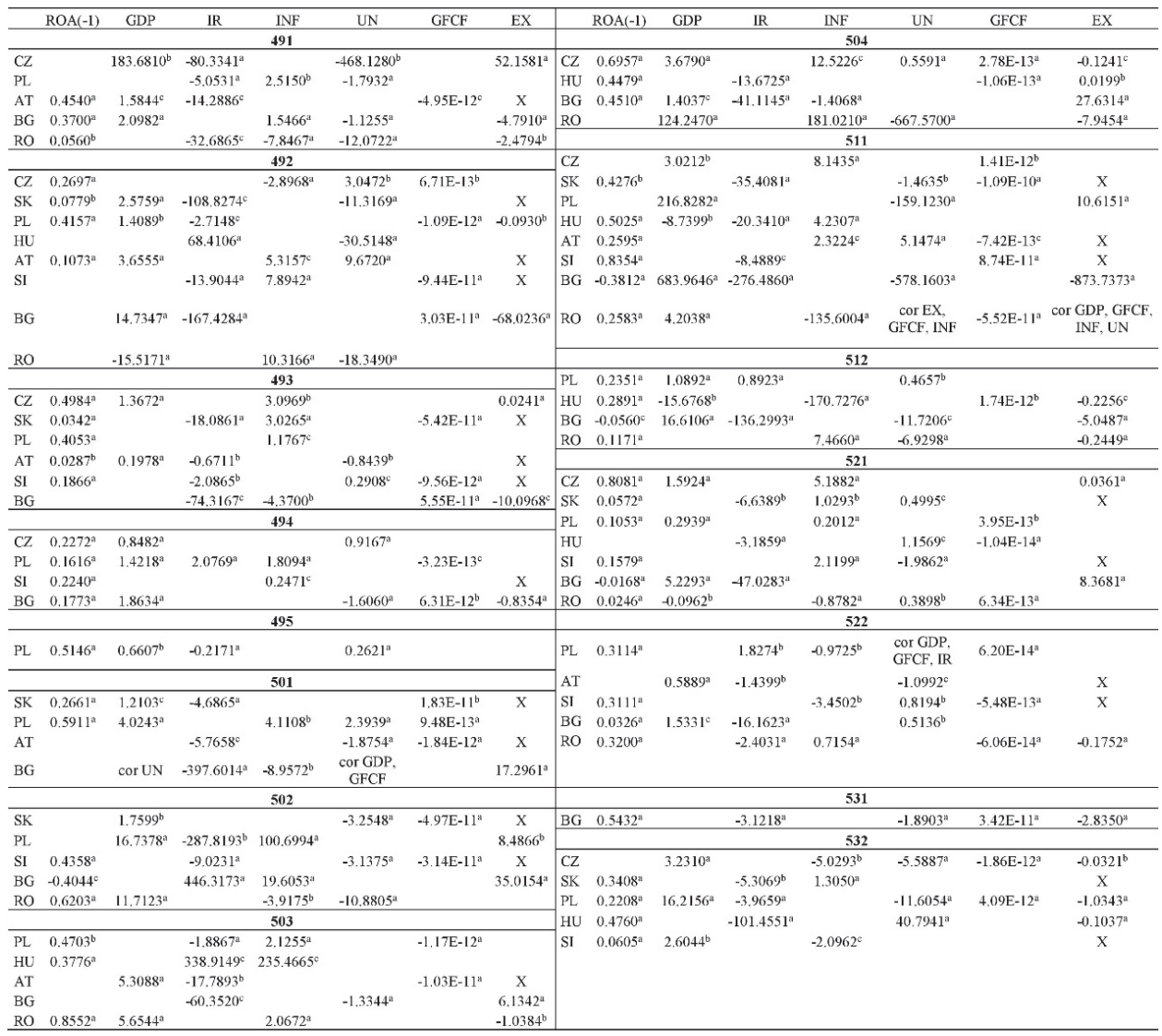

Source: Author's own calculations based on data of Orbis database

Symbols: ${ }^{a},{ }^{b}$ and ${ }^{c}$ indicate significance at $1 \%, 5 \%$ and $10 \%$.

As for Polish companies, we did not find a result in only one subindustry - 531 . The remaining subindustries have a result for at least one profitability indicator. Overall, the 
reference interest rate and the development of the economy have the greatest impact on the profitability level. The level of return on assets is affected by the development of the economy $(495,511,512,521,532)$, the reference interest rate $(491,492,494,502,522)$ and the inflation rate $(493,501,503)$. The positive impact of economic development is obvious, as the Polish economy is one of the few economies that did not experience an economic downturn during the 2008/2009 financial crisis, the ensuing European debt crisis, the global slowdown in 2012/2013 and the global downturn at the end of the period under review. During the period under review, this economy grew by an average of 3.6\% year on year. Economic prosperity increased the disposable income of households (increase in profits) as well as companies (possibility of reinvesting in other assets). The reference interest rate had both a positive and a negative impact. The negative impact was due to the decrease of this rate from 4.5 to $1.5 \%$ during the period under review, which resulted in cheaper debt financing, by which other assets could be purchased to increase production. On the other hand, the interest rate was high in the first half of the period, which could have had a positive impact due to, for example, the fact that companies borrowed at higher costs and could still increase their profitability. The inflation rate had a positive impact on the return on assets. The average inflation rate was around $1.5 \%$, which may have reduced the real expression of interest rates, which may have become lower giving companies a room for debt financing; this way, they could acquire additional assets and by them to increase production and consequently the profit. The level of return on equity was mostly affected by the same determinants as in the case of ROA - economic development $(491,494,495,512)$, interest rate $(492,493,501,503,532)$ and inflation rate $(502,511)$. These are the same directions of impact as for ROA and the explanation is therefore the same; only the assets for additional production are not increased but the equity is, out of which further development and purchase of such assets can be financed. The level of profitability of sales was again influenced by the reference interest rate $(491,492,493,495$, $504)$, the development of the economy $(501,502)$ and, in addition, the unemployment rate $(511,532)$. As with ROA and ROE, the impact of the reference interest rate and economic development has the same rationale and, in addition to the effect on assets, equity, these variables may also affect sales. The negative impact of the unemployment rate is evident in view of the decline in this rate from 10.3 to $3.9 \%$ during the period under review. Along with this decrease, the employed population increased, which meant an increase in the disposable income that could be spent on products in the given subindustries.

No results for Hungarian companies can be found in subindustries 491, 495, 501, 502 and 531. The remaining subindustries have a result for at least one profitability indicator. Overall, the rate of reference interest rate, which clearly dominates in twelve out of seventeen cases, and the rate of inflation have the greatest impact on profitability. Both determinants have both positive and negative impacts, with expected impacts prevailing. The greatest impact of the reference interest rate can be found in subindustries 492, 503, 504, 511, 521, 532 for ROA, 494, 503, 512, 522 for ROE and 512 for ROS. On the contrary, the greatest impact of the inflation rate can be found in subindustries 512 for ROA, 492 for ROE and 492, 493, 503 for ROS. The negative impact of the reference rate is seen due to a decrease in the rate from 7.0 to $0.9 \%$ during the period under review, which resulted in cheaper debt financing, based on which additional assets could be purchased to increase output; at the same time, additional resources could be invested in equity in this way. On the other hand, the interest rate was high in the first half of the period, which could 
have had a positive impact due to e.g. the fact that companies borrowed at higher costs and could still increase their profitability. The positive impact of the inflation rate on the profitability level could be due to the fact that the average inflation rate was around 2.4\%; such situation could reduce the real expression of interest rates, which could thus become lower and give companies a room for debt financing; companies could acquire additional assets and thus increase their production and consequently their profitability. The negative influence of the inflation rate is difficult to justify, but occurs in only one case (512). The good development of these two variables could, through debt financing, lead to an increase in assets, equity and sales, which led to increase in profitability in most cases.

Table 3: GMM results for ROE indicator

\begin{tabular}{|c|c|c|c|c|c|c|c|c|c|c|c|c|c|c|c|}
\hline & $\mathrm{ROE}(-1)$ & GDP & IR & INF & UN & GFCF & EX & & $\mathrm{ROE}(-1)$ & GDP & IR & INF & UN & $\mathrm{GFCF}$ & EX \\
\hline & & & & 491 & & & & \multicolumn{8}{|c|}{503} \\
\hline $\mathrm{CZ}$ & & $211.4936^{\mathrm{a}}$ & $-253.5511^{\mathrm{a}}$ & & & $-3.80 \mathrm{E}-11^{\mathrm{a}}$ & $0.2633^{\mathrm{a}}$ & PL & $0.6456^{\mathrm{b}}$ & & $-4.1651^{\mathrm{a}}$ & & $-1.9221^{\mathrm{b}}$ & & $-0.1465^{b}$ \\
\hline PL & $-0.2906^{\mathrm{a}}$ & $359.4741^{\mathrm{a}}$ & & & $-108.6836^{b}$ & & $-27.8033^{a}$ & $\mathrm{HU}$ & & & $-399.2830^{\mathrm{a}}$ & $103.6910^{\mathrm{a}}$ & & $-2.43 \mathrm{E}-11^{\mathrm{a}}$ & \\
\hline AT & & & $-233.3422^{\mathrm{a}}$ & $10.6431^{a}$ & & $8.27 \mathrm{E}-11^{\mathrm{b}}$ & $\mathrm{x}$ & AT & $0.7858^{\mathrm{a}}$ & & $-48.5096^{\mathrm{a}}$ & $3,5593^{\mathrm{a}}$ & $-10.7748^{\mathrm{b}}$ & & $\mathrm{X}$ \\
\hline BG & $-0.3526^{\mathrm{a}}$ & $9.1687^{\mathrm{b}}$ & & & $-4.7412^{\mathrm{b}}$ & $7.78 \mathrm{E}-11^{\mathrm{a}}$ & $-43.9699^{\mathrm{a}}$ & BG & & $6.1794^{\mathrm{a}}$ & & $4.3508^{\mathrm{b}}$ & & $-9.39 \mathrm{E}-12^{\mathrm{a}}$ & $3.2139^{2}$ \\
\hline $\mathrm{RO}$ & $0.4862^{\mathrm{c}}$ & & $125.1177^{\mathrm{a}}$ & $55.5134^{\mathrm{a}}$ & & $5.23 \mathrm{E}-11^{b}$ & $-6.4560^{\mathrm{a}}$ & RO & & $13.5443^{\mathrm{a}}$ & $15.4626^{\mathrm{b}}$ & & $-16.1875^{\mathrm{a}}$ & & \\
\hline \multicolumn{8}{|c|}{492} & \multicolumn{8}{|c|}{504} \\
\hline $\mathrm{CZ}$ & $-0.1277^{\mathrm{a}}$ & $1.5249^{\mathrm{b}}$ & & $4.4825^{\mathrm{a}}$ & $-6.6299^{a}$ & $1.25 \mathrm{E}-12^{\mathrm{a}}$ & & $\mathrm{CZ}$ & & $14.7023^{\mathrm{b}}$ & & $21.7674^{x}$ & $-31.3689^{\mathrm{b}}$ & $3.14 \mathrm{E}-12^{\mathrm{a}}$ & \\
\hline SK & $-0.1211^{\mathrm{a}}$ & $340.8669^{\mathrm{a}}$ & cor INF & $478.6595^{\mathrm{a}}$ & & $\operatorname{cor} \mathrm{UN}$ & $\mathrm{X}$ & BG & & & $-42.0258^{\mathrm{a}}$ & $-19.5475^{\mathrm{a}}$ & & & $112.6670^{\mathrm{c}}$ \\
\hline PL & $-0.0624^{a}$ & & $-35.7519^{\mathrm{a}}$ & & $-14.3289^{a}$ & & $-1.0103^{a}$ & RO & $0.5009^{\mathrm{a}}$ & $21.5853^{\mathrm{a}}$ & $18.4324^{\mathrm{b}}$ & & $-14.8671^{a}$ & & \\
\hline $\mathrm{HU}$ & $0.3899^{\mathrm{a}}$ & $\begin{array}{c}\text { cor EX, } \\
\text { GFCF, IR, } \\
\text { UN }\end{array}$ & & $461.4614^{a}$ & $162.0244^{\mathrm{a}}$ & & & \multicolumn{8}{|c|}{511} \\
\hline AT & $0,0339^{\mathrm{b}}$ & & $-2.1479^{\mathrm{a}}$ & $34.0472^{\mathrm{a}}$ & & $-9.15 \mathrm{E}-12^{\mathrm{b}}$ & $\mathrm{x}$ & $\mathrm{CZ}$ & $-0.2641^{\mathrm{a}}$ & $45.1167^{\mathrm{a}}$ & & $8.3354^{\mathrm{a}}$ & & $8.32 \mathrm{E}-12^{b}$ & \\
\hline SI & $0.2750^{\mathrm{a}}$ & $-77.2070^{\mathrm{a}}$ & & $804.3940^{c}$ & $-116.4920^{b}$ & & $\mathrm{X}$ & SK & & $68.5519^{\mathrm{a}}$ & $-107.6660^{b}$ & & $-6.6781^{a}$ & & X \\
\hline $\mathrm{BG}$ & & & $-66.6966^{\mathrm{b}}$ & $-10.1458^{a}$ & cor GDP, GFCF & $-5.17 \mathrm{E}-11^{\mathrm{b}}$ & $65.0087^{a}$ & PL & $-0.1577^{u}$ & & & $-50.3261^{*}$ & & $4.08 \mathrm{E}-12^{4}$ & $-1.2003^{a}$ \\
\hline \multicolumn{8}{|c|}{493} & $B G$ & $0.2320^{\mathrm{a}}$ & & $-575.1542^{c}$ & & $-26.4749^{b}$ & & $47.9899^{\mathrm{b}}$ \\
\hline PL & $0.0215^{\mathrm{a}}$ & & $-10.7940^{\mathrm{a}}$ & $5.1793^{\mathrm{a}}$ & $-3.8299^{a}$ & & & RO & $0.7470^{\mathrm{a}}$ & $-14.0751^{\mathrm{a}}$ & & $36.9854^{\circ}$ & $\begin{array}{c}\text { cor EX, } \\
\text { GFCF, INF }\end{array}$ & $-2.82 \mathrm{E}-12^{\mathrm{a}}$ & $\begin{array}{c}\text { cor GDP, } \\
\text { GFCF, INF, } \\
\text { UN }\end{array}$ \\
\hline SI & $-0.1832^{a}$ & $13.9444^{\mathrm{a}}$ & & & $-12.8782^{\mathrm{a}}$ & $-2.70 \mathrm{E}-10^{\mathrm{a}}$ & $\mathrm{x}$ & & & & & 512 & & & \\
\hline \multicolumn{8}{|c|}{494} & PL & $-0.3086^{a}$ & $18.5838^{a}$ & & $6.0330^{\mathrm{b}}$ & $-14.0273^{b}$ & \multirow{4}{*}{$1.99 \mathrm{E}-10^{\circ}$} & \\
\hline PL & $0.0092^{\mathrm{a}}$ & $3.8353^{\mathrm{a}}$ & & & $-2.1143^{b}$ & & $0.2023^{\mathrm{a}}$ & $\mathrm{HU}$ & & & $-892.3692^{\mathrm{a}}$ & & $353.5926^{\circ}$ & & $0.9047^{b}$ \\
\hline $\mathrm{HU}$ & $0.0408^{\mathrm{a}}$ & & $-45.6828^{c}$ & \multirow{3}{*}{$-2.2283^{a}$} & $21,5118^{\mathrm{c}}$ & & \multirow{3}{*}{$\begin{array}{c}X \\
-0.9323^{a}\end{array}$} & BG & $0.0038^{\mathrm{a}}$ & & $-398.7160^{\mathrm{a}}$ & $-15.7518^{a}$ & & & $35.8922^{\mathrm{a}}$ \\
\hline AT & $-0.476 \mathrm{l}^{\mathrm{a}}$ & $1.4667^{\mathrm{a}}$ & & & $-12.1173^{\mathrm{a}}$ & $-5.95 \mathrm{E}-12^{\mathrm{b}}$ & & $\mathrm{RO}$ & & $-38.3173^{\mathrm{a}}$ & & $25.659 \mathrm{l}^{\mathrm{b}}$ & $-70.9017^{b}$ & & $-0.9475^{\mathrm{a}}$ \\
\hline RO & $-0.0005^{\mathrm{b}}$ & & $9.1373^{\mathrm{a}}$ & & $-51.2206^{\mathrm{a}}$ & $2.17 \mathrm{E}-11^{\mathrm{b}}$ & & \multicolumn{8}{|c|}{521} \\
\hline \multicolumn{8}{|c|}{495} & SI & $-0.4370^{\mathrm{a}}$ & & $-77.6119^{a}$ & $80.8051^{a}$ & & $4.13 \mathrm{E}-10^{\circ}$ & $\mathrm{X}$ \\
\hline PL & $0.2097^{c}$ & $7.0181^{b}$ & & & $-1.2012^{c}$ & $3.35 \mathrm{E}-12^{\circ}$ & & BG & $0.0105^{\mathrm{a}}$ & $46.8493^{\mathrm{a}}$ & & & $-19.0552^{\mathrm{a}}$ & & $119.6255^{\mathrm{a}}$ \\
\hline \multicolumn{8}{|c|}{501} & \multicolumn{8}{|c|}{522} \\
\hline SK & $0.3083^{\mathrm{a}}$ & $35.2790^{\mathrm{a}}$ & & $91.2420^{\mathrm{a}}$ & & $3.77 \mathrm{E}-08^{\mathrm{a}}$ & $X$ & $\mathrm{CZ}$ & $-0.0647^{\mathrm{a}}$ & $48.1830^{\mathrm{a}}$ & $-2.6090^{b}$ & & $\begin{array}{l}\text { cor GDP, } \\
\text { GFCF, IR }\end{array}$ & $-2.24 \mathrm{E}-12^{\mathrm{a}}$ & \\
\hline PL & $0.4450^{\mathrm{b}}$ & & $-15.5597^{\mathrm{a}}$ & & $-4.7548^{\mathrm{a}}$ & $-9.30 \mathrm{E}-14^{b}$ & & $\mathrm{HU}$ & $0.0471^{\mathrm{a}}$ & & $-152.4292^{\mathrm{a}}$ & $97.1827^{\mathrm{a}}$ & & $-8.52 \mathrm{E}-13^{\mathrm{a}}$ & \\
\hline AT & $-0.4742^{a}$ & $4,0389^{\mathrm{a}}$ & & $3.8616^{\mathrm{a}}$ & & $-1.23 \mathrm{E}-11^{\mathrm{a}}$ & $\mathrm{x}$ & AT & $0.0045^{\mathrm{a}}$ & $2.3435^{\mathrm{b}}$ & & $1.6225^{\circ}$ & & $-3.55 \mathrm{E}-12^{\mathrm{c}}$ & $\mathrm{x}$ \\
\hline $\mathrm{BG}$ & $-0.2597^{\mathrm{a}}$ & cor UN & $-75.5698^{\mathrm{a}}$ & $-11.5271^{a}$ & cor GDP & & $-192.0880^{\mathrm{a}}$ & BG & $0.0415^{b}$ & $3.4157^{\mathrm{a}}$ & $-60.2391^{\circ}$ & & & $-2.06 \mathrm{E}-11$ & $-1.5796^{a}$ \\
\hline \multicolumn{8}{|c|}{502} & RO & $-0.0079^{\mathrm{a}}$ & & $22.9444^{\mathrm{a}}$ & & $12.2770^{\mathrm{a}}$ & & $1.9645^{b}$ \\
\hline SK & $0.4142^{\mathrm{a}}$ & $40.2420^{\mathrm{a}}$ & & $56.9737^{\mathrm{a}}$ & $-37.3669^{b}$ & & $\mathrm{X}$ & \multicolumn{8}{|c|}{531} \\
\hline PL & & & $-33.9285^{a}$ & $52.5894^{4}$ & & $5.18 \mathrm{E}-11^{*}$ & $6.1460^{\mathrm{a}}$ & BG & $0.5821^{\mathrm{a}}$ & $2.2768^{\mathrm{b}}$ & $-94.9194^{a}$ & $3.2168^{\mathrm{a}}$ & & & $-15.9346^{a}$ \\
\hline SI & $0.6905^{\mathrm{a}}$ & & $-46.9718^{\mathrm{a}}$ & & $-7.277 \mathrm{l}^{\mathrm{a}}$ & $8.15 \mathrm{E}-10^{c}$ & $\mathrm{X}$ & \multicolumn{8}{|c|}{532} \\
\hline BG & & $16.5002^{\mathrm{a}}$ & & & $-8.6240^{a}$ & & $-35.5643^{\mathrm{b}}$ & $\mathrm{CZ}$ & $-0.2936^{a}$ & $1.6049^{\mathrm{b}}$ & $-28.4197^{a}$ & & & & $-0.2769^{4}$ \\
\hline RO & $0.5017^{\mathrm{a}}$ & & $-88.4734^{a}$ & $36.2303^{b}$ & & $-9.15 \mathrm{E}-12^{\mathrm{a}}$ & & $\begin{array}{l}\text { SK } \\
\text { PL }\end{array}$ & $\begin{array}{l}-0.0550^{\mathrm{a}} \\
-0.1130^{\mathrm{a}}\end{array}$ & $8.8895^{\mathrm{a}}$ & $43.5241^{\mathrm{a}}$ & $\begin{array}{c}7.7843^{\mathrm{a}} \\
-31.2437^{\mathrm{a}}\end{array}$ & $\begin{array}{c}-2.3074^{\mathrm{a}} \\
-13.6170^{\mathrm{a}}\end{array}$ & $2.06 \mathrm{E}-10$ & $\mathrm{x}$ \\
\hline & & & & & & & & SI & $0.2079^{\mathrm{a}}$ & $-9.4343^{a}$ & $-49.7960^{b}$ & & $5.5854^{\mathrm{a}}$ & & $\mathrm{X}$ \\
\hline
\end{tabular}

Source: Author's own calculations based on data from Orbis database

Symbols: ${ }^{a},{ }^{b}$ and ${ }^{c}$ indicate significance at $1 \%, 5 \%$ and $10 \%$.

As for Austrian companies, unfortunately, we did not find any results for subindustries 495, 502,512 and 531. The remaining subindustries have a result for at least one profitability indicator. Overall, the reference interest rate has the greatest impact on the profitability level followed by the unemployment rate, economic development and the inflation rate. The return on assets is partly affected by the reference interest rate $(491,501,503,522)$ and partly by the unemployment rate $(492,493,511)$. The negative impact of the reference interest rate can be explained by the fact that the rate was on average $0.3 \%$ during the period under review, which led to the possibility of cheap indebtedness, which could be used to acquire additional assets, which could lead to higher profits. The effect of the unemployment rate is ambiguous, which may be due to the fact that this rate fluctuated 
between 4.6 and $6.0 \%$. Periods of ups and downs alternated, which could lead to positive or negative impacts in the subindustries concerned. The sales profitability level is also affected by these two determinants, while the unemployment rate affects subindustries 491, 501, 511 and the reference interest rate affects subindustries 492, 494, 521 and 532. All cases meet our assumptions and therefore, the explanation is the same as for ROA indicator. The level of return on equity was affected by all four mentioned determinants - 491 and 503 by reference interest rate, 501 and 522 by economic development, 494 by unemployment rate and 492 by inflation rate. The impact of the reference interest rate and the inflation rate has already been explained. As for the average inflation rate, it was around $1.9 \%$; it may have reduced the real expression of interest rates, which could have become even lower giving companies a room for debt financing; through an inflow of funds into equity, companies could finance their further production and development thus create more profit. The Austrian economy grew by an average of $1.6 \%$ year on year during the period under review. There was also no economic downturn, so it can be said that this economy coped very well with crises and economic external influences and companies were surrounded by an environment enabling them to grow their prosperity.

Results for Slovenian companies are missing in subindustries 491, 495, 501, 503, 504 and 531. The remaining subindustries have a result for at least one profitability indicator. Overall, the reference interest rate has the greatest impact on the profitability level followed by the inflation rate and economic development. The reference interest rate has a negative impact in all cases: 492, 493, 502, 511 for ROA; 502, 532 for ROE; 493, 532 for ROS. The negative impact is represented by the same effects as in the case of Austrian and Slovak companies, as the monetary policy of all three economies is managed by the European Central Bank. During the period under review, the interest rate was $0.3 \%$ on average, which led to the cheap indebtedness; such situation enabled to acquire additional assets, which would lead to higher profits. Similarly, these funds could increase equity. Everything could lead to growing sales and profits. The profitability level of subindustries 532 (ROA), $493(\mathrm{ROE})$ and 521 (ROS) is positively affected by economy development. At the beginning of the period, the Slovenian economy suffered from the effects of the financial crisis of 2008/2009, which had the same course in Slovenia as in the United States. Also in this economy, a real estate bubble and a credit cripple occurred and after this crisis, moreover in 2013, this economy went through a banking crisis due to excessive risk-taking poor management of state banks as well as insufficient supervision. However, the economy recovered from the crises and achieved solid growth of over $2 \%$ in the second half of the period under review. Ultimately, good growth over half of the period under review had a positive impact on profitability. The profitability level in subindustries 494 and 521 (ROA), 492 and 521 (ROE) is affected by the inflation rate, which has a predominantly positive impact. The average inflation rate was around $1.2 \%$, which, as in the remaining economies, may have reduced the real expression of interest rates; those may have become even lower giving companies a room for debt financing; this way, companies could to increase their profitability through the resources inflowing into assets and equity thus further development could be financed to increase future profits.

As for Bulgarian companies, only one subindustry (495) was not possible to obtain results for. The remaining subindustries have a result for at least one profitability indicator. Overall, the reference interest rate has the greatest impact on the profitability level followed by 
the exchange rate and economic development. The impact of the reference interest rate is negative in almost all cases with one exception - 502 for ROA. The negative impact on the rate of the company's assets appreciation, equity and sales can be justified by the fact that the Bulgarian reference interest rate averaged $0.05 \%$ over the period, which clearly means very low costs when acquiring debt financing, based on which further assets could be provided, thus equity could increase as well as sales, production and profits. The impact of the exchange rate on the euro is very peculiar, as the Bulgarian lev is practically fixed on the euro and exchange rate movements are of very low amplitude to be able to move significantly with the amount of financial resources in conversion. However, in Bulgaria during 2010-2018, the value of imports prevailed the value of exports each year and therefore, an importer is affected mainly by the currency weakening. The currency weakened in 2010, 2012, 2013, 2014, 2017 and 2018, which has a negative impact on imports. This negative impact outweighed the impact on profitability indicators. A positive impact was found for subindustries 504 and 521 (ROE) and 504 (ROS). Here it would be necessary to find out what are the values of imports and exports in these subindustries. The positive impact of economic development was found in subindustries 491, 494 (ROA) and 503 (ROE). The Bulgarian economy was also developing at a good pace averaging 2.2\% over the period under review and even 3.2\% year on year in the second half. Businesses were prospering along with the economy and thus they were able to increase their assets and equity.

Table 4: GMM results for ROS indicator

\begin{tabular}{|c|c|c|c|c|c|c|c|c|c|c|c|c|c|c|c|}
\hline & ROS $(-1)$ & GDP & IR & INF & UN & GFCF & EX & & ROS $(-1)$ & GDP & IR & INF & UN & $\mathrm{GFCF}$ & EX \\
\hline \multicolumn{8}{|c|}{491} & \multicolumn{8}{|c|}{504} \\
\hline $\mathrm{CZ}$ & $0.1834^{\mathrm{a}}$ & $161.3926^{b}$ & & $355.0653^{b}$ & $-91.5949^{b}$ & cor UN & & $\mathrm{CZ}$ & $0.6439^{\mathrm{b}}$ & & $-1.7164^{\mathrm{a}}$ & & $-0.3275^{\mathrm{a}}$ & $9.54 \mathrm{E}-14^{\mathrm{a}}$ & \\
\hline PL & $0.0011^{\mathrm{a}}$ & & $21.6421^{\mathrm{b}}$ & & $-2.9349^{a}$ & $-1.23 \mathrm{E}-11^{\mathrm{a}}$ & & PL & & $3,0221^{\mathrm{b}}$ & $-39.3219^{a}$ & $25.0293^{\mathrm{a}}$ & & & $0.0445^{\mathrm{a}}$ \\
\hline AT & $0.5519^{\mathrm{a}}$ & $1.7246^{\mathrm{a}}$ & & $-4.5972^{\mathrm{b}}$ & $-6.6590^{\mathrm{a}}$ & & X & $\mathrm{BG}$ & $0.3314^{a}$ & & $-3,4158^{\mathrm{a}}$ & & $1.1699^{b}$ & $-3.08 \mathrm{E}-12^{\mathrm{a}}$ & $36.4988^{b}$ \\
\hline $\mathrm{BG}$ & $0.3358^{\mathrm{a}}$ & & $-66.8085^{\mathrm{a}}$ & $2.9966^{\mathrm{a}}$ & & $6.8 \mathrm{E}-12^{\mathrm{a}}$ & $-8.7811^{\mathrm{a}}$ & RO & $0.0676^{\mathrm{a}}$ & $59.4242^{a}$ & & $24.3876^{\mathrm{a}}$ & $-17.4191^{a}$ & & $8.2514^{\mathrm{a}}$ \\
\hline RO & & $12.9072^{\mathrm{a}}$ & $-8.4337^{b}$ & & $-8.9448^{\mathrm{a}}$ & & $-1.7620^{\mathrm{a}}$ & \multicolumn{8}{|c|}{511} \\
\hline \multicolumn{8}{|c|}{492} & $\mathrm{CZ}$ & $0.4506^{\mathrm{c}}$ & & $-11.2147^{a}$ & $4.6015^{a}$ & & $8.56 \mathrm{E}-13^{b}$ & \\
\hline $\mathrm{CZ}$ & $-0.1157^{b}$ & & $-2.1739^{\mathrm{a}}$ & $0.6507^{\mathrm{b}}$ & & $3.42 \mathrm{E}-13^{b}$ & $0,0274^{\mathrm{a}}$ & SK & $0.4056^{\mathrm{a}}$ & $1.2489^{a}$ & & $1.3131^{\mathrm{b}}$ & $1.1726^{\mathrm{a}}$ & & $x$ \\
\hline SK & $0.0056^{\mathrm{c}}$ & $6.2741^{\mathrm{a}}$ & & $9.1982^{\mathrm{a}}$ & $-5.5608^{\mathrm{a}}$ & $\operatorname{cor} \mathrm{UN}$ & $\mathrm{X}$ & PL & $-0.0488^{\mathrm{a}}$ & $1.5282^{\mathrm{a}}$ & & $1.7366^{\mathrm{a}}$ & $-2.2027^{\mathrm{a}}$ & & \\
\hline PL & $0.1308^{\mathrm{a}}$ & $2.7867^{\mathrm{a}}$ & $-5.5874^{\mathrm{a}}$ & $2.9966^{\mathrm{a}}$ & $-1.9267^{\mathrm{a}}$ & & & $\mathrm{HU}$ & $0.4570^{\mathrm{a}}$ & & $364.7665^{\mathrm{a}}$ & & $-164.1973^{\mathrm{a}}$ & & $-0.2624^{\mathrm{a}}$ \\
\hline HU & $0.1348^{\mathrm{a}}$ & & & $29.0046^{\mathrm{a}}$ & $18.2293^{a}$ & & $0.0384^{\mathrm{b}}$ & $\mathrm{AT}$ & $0.7186^{\mathrm{a}}$ & $3.7498^{\mathrm{a}}$ & & $0.4354^{a}$ & -5.3944 & $-6.41 \mathrm{E}-12^{\mathrm{a}}$ & X \\
\hline AT & $0.2625^{\mathrm{a}}$ & $3.7333^{\mathrm{c}}$ & $-16.6656^{b}$ & & $9.9435^{\mathrm{a}}$ & & $\mathrm{X}$ & BG & $0.0027^{\mathrm{a}}$ & $38.2461^{\mathrm{b}}$ & $-160.5286^{a}$ & $-8.0948^{c}$ & & & $9.5196^{\mathrm{a}}$ \\
\hline$B G$ & $0.6365^{\mathrm{a}}$ & & $-242.6523^{\mathrm{a}}$ & $45.1652^{\mathrm{a}}$ & & & $-710.3704^{a}$ & RO & $-0.2305^{\mathrm{a}}$ & $-19.8570^{\mathrm{a}}$ & $283.0392^{\mathrm{a}}$ & $107.8700^{\mathrm{a}}$ & $\begin{array}{c}\text { cor EX, GFCF, } \\
\text { INF }\end{array}$ & & $\begin{array}{c}\text { cor GDP, GFCF, } \\
\text { INF, UN }\end{array}$ \\
\hline RO & $-0.5509^{\mathrm{a}}$ & $-4.9995^{\circ}$ & $-6.5698^{c}$ & & $-13.0775^{a}$ & & $-1.4292^{\mathrm{a}}$ & \multicolumn{8}{|c|}{512} \\
\hline \multicolumn{8}{|c|}{493} & $\mathrm{HU}$ & $0.6405^{\text {a }}$ & & $-6.8249^{\mathrm{a}}$ & $4.4795^{\mathrm{a}}$ & & $3.86 \mathrm{E}-14^{a}$ & \\
\hline PL & $0.0804^{a}$ & & $2.9808^{\mathrm{a}}$ & $-2.4045^{\mathrm{a}}$ & & $-8.17 \mathrm{E}-13^{b}$ & $-0.1368^{a}$ & BG & & $173.3813^{a}$ & $-180.4230^{b}$ & & $-94.7771^{a}$ & & $-200.0957^{a}$ \\
\hline $\mathrm{HU}$ & $0.0005^{\mathrm{a}}$ & $-1.0012^{\mathrm{a}}$ & & $2.1205^{\mathrm{a}}$ & $1.8751^{\mathrm{a}}$ & & $0.0050^{\mathrm{a}}$ & RO & & $-3.9912^{\mathrm{b}}$ & & $2.9426^{\mathrm{a}}$ & & $1.41 \mathrm{E}-11^{\mathrm{b}}$ & $-0.2010^{\mathrm{a}}$ \\
\hline SI & $0.3625^{\mathrm{a}}$ & & $-3.2787^{\mathrm{a}}$ & & $-0.4806^{\mathrm{b}}$ & $-1.25 \mathrm{E}-11^{\mathrm{b}}$ & X & \multicolumn{8}{|c|}{521} \\
\hline $\mathrm{BG}$ & $0.0698^{\mathrm{a}}$ & & $-10.7405^{\mathrm{b}}$ & $0.7752^{\mathrm{a}}$ & $-1,0183^{\circ}$ & & & AT & $-0.5740^{a}$ & $5.4310^{4}$ & $-33,9128^{a}$ & & & $-1,93 \mathrm{E}-11$ & $x$ \\
\hline RO & $0.0821^{a}$ & $5.7285^{\mathrm{a}}$ & $4.5462^{\mathrm{b}}$ & $2.3514^{\mathrm{a}}$ & & $1.77 \mathrm{E}-12^{\mathrm{a}}$ & $-0.2325^{\mathrm{b}}$ & SI & & $14.4956^{a}$ & & $12.7882^{\mathrm{a}}$ & $-12.9134^{\mathrm{a}}$ & & $\mathrm{X}$ \\
\hline \multicolumn{8}{|c|}{494} & BG & $0.2148^{\mathrm{a}}$ & & $-101.0319^{\mathrm{a}}$ & & $-4.3475^{\mathrm{a}}$ & & $-12.0623^{a}$ \\
\hline SK & & $0.2012^{c}$ & $-0.9471^{b}$ & $0.3764^{\mathrm{a}}$ & & $1.95 \mathrm{E}-14^{a}$ & $\mathrm{X}$ & \multicolumn{8}{|c|}{522} \\
\hline AT & $0.2106^{\mathrm{a}}$ & & $-0.8498^{\mathrm{a}}$ & & $-0.1296^{\mathrm{a}}$ & & X & SK & & $1.7258^{\mathrm{a}}$ & $-3.7974^{\mathrm{a}}$ & & $-2.3869^{\mathrm{a}}$ & $-2.85 \mathrm{E}-12^{\mathrm{a}}$ & $\mathrm{X}$ \\
\hline RO & $0.0247^{\mathrm{b}}$ & $1.8529^{\mathrm{a}}$ & & $0.9614^{\mathrm{a}}$ & $-3.9691^{\mathrm{a}}$ & & $-0.1266^{\mathrm{A}}$ & \multicolumn{8}{|c|}{531} \\
\hline \multicolumn{8}{|c|}{495} & BG & & $39.5154^{\mathrm{a}}$ & $-381.9642^{\mathrm{b}}$ & & & & $-62.8844^{a}$ \\
\hline PL & $0.9936^{\mathrm{a}}$ & & $4.5926^{\mathrm{a}}$ & $-4.0267^{\mathrm{b}}$ & $-0.4985^{a}$ & & $-0.1712^{\mathrm{a}}$ & \multicolumn{8}{|c|}{ 年 } \\
\hline \multicolumn{8}{|c|}{501} & $\mathrm{CZ}$ & $0.5429^{\mathrm{a}}$ & & $2.1967^{\mathrm{a}}$ & $-2.9189^{\mathrm{a}}$ & $-1.5923^{b}$ & & \\
\hline SK & & & $-3.3904^{b}$ & $-0.5728^{b}$ & & $8.45 \mathrm{E}-13^{\mathrm{a}}$ & $\mathrm{X}$ & SK & $0.1792^{\mathrm{a}}$ & & $-2.5152^{\mathrm{a}}$ & & $0.2559^{\mathrm{a}}$ & $1.28 \mathrm{E}-11^{\mathrm{a}}$ & $\mathrm{X}$ \\
\hline PL & $0.7676^{\mathrm{a}}$ & $5.0309^{\mathrm{a}}$ & & $4.1286^{a}$ & $-1.8928^{\mathrm{a}}$ & & & PL & $0.2615^{\prime \prime}$ & $1.1534^{a}$ & & $1.4124^{\prime \prime}$ & $-2.2620^{a}$ & & $-0.0378^{\mathrm{a}}$ \\
\hline AT & & $2.4640^{\mathrm{b}}$ & $-108.6200^{\mathrm{a}}$ & & $-181.7359^{\mathrm{a}}$ & & X & AT & $0.1536^{\mathrm{a}}$ & $3.3243^{\mathrm{a}}$ & $-8.8411^{\mathrm{a}}$ & & $-5.4125^{a}$ & $-6.19 \mathrm{E}-12^{\mathrm{a}}$ & X \\
\hline $\mathrm{BG}$ & $0.2836^{\mathrm{c}}$ & cor UN & $-155.1692^{\mathrm{a}}$ & & cor GDP & $-1.74 \mathrm{E}-11^{\mathrm{a}}$ & $-9.1903^{a}$ & SI & $0.4671^{\mathrm{a}}$ & & $-6.3449^{b}$ & & $0.7064^{\mathrm{a}}$ & & $\mathrm{X}$ \\
\hline \multicolumn{8}{|c|}{502} & $\mathrm{BG}$ & $0.4225^{\prime \prime}$ & $3.1682^{\mathrm{s}}$ & & $0.9727^{\mathrm{c}}$ & $-1.6073^{a}$ & & $-5.1331^{4}$ \\
\hline SK & & $1.5639^{\mathrm{a}}$ & $-3,8336^{\mathrm{b}}$ & & & $-1.47 \mathrm{E}-11^{\mathrm{a}}$ & $\mathrm{X}$ & RO & $0.0535^{\mathrm{a}}$ & & $0.5353^{\mathrm{a}}$ & $-0.9240^{b}$ & & $2.3 \mathrm{E}-14^{\mathrm{b}}$ & $-0.1858^{b}$ \\
\hline PL & & $43.6962^{\mathrm{a}}$ & & $4.3103^{\mathrm{a}}$ & $-8.4531^{a}$ & & $-3.4923^{a}$ & & & & & & & & \\
\hline$B G$ & & & $-104.7630^{\mathrm{a}}$ & & & $1.37 \mathrm{E}-09^{\circ}$ & $-217.5458^{a}$ & & & & & & & & \\
\hline $\mathrm{RO}$ & $0.6001^{4}$ & $20.6812^{\mathrm{a}}$ & & $-10.1810^{b}$ & $25.0886^{\mathrm{a}}$ & $-3.5 \mathrm{E}-12^{\mathrm{a}}$ & & & & & & & & & \\
\hline \multicolumn{8}{|c|}{503} & & & & & & & & \\
\hline $\mathrm{HU}$ & & & & $13.1092^{\mathrm{a}}$ & $8.1412^{a}$ & $-9.87 \mathrm{E}-14^{\mathrm{b}}$ & & & & & & & & & \\
\hline $\mathrm{BG}$ & $-0.1299^{\mathrm{a}}$ & $15.1666^{\mathrm{a}}$ & $-67.1012^{\mathrm{a}}$ & $10.5605^{b}$ & & & $24.8806^{\mathrm{a}}$ & & & & & & & & \\
\hline RO & $0.9702^{\mathrm{a}}$ & & $8.3291^{\mathrm{a}}$ & & $-16.7413^{b}$ & & $-0.2565^{\mathrm{a}}$ & & & & & & & & \\
\hline
\end{tabular}

Source: Author's own calculations based on data from Orbis database

Symbols: ${ }^{a},{ }^{b}$ and ${ }^{c}$ indicate significance at $1 \%, 5 \%$ and $10 \%$. 
No results for Romanian companies can be found in subindustries 495, 501 and 532. The remaining subindustries have a result for at least one profitability indicator. Overall, the unemployment rate has the greatest impact on profitability followed by economic development, the reference interest rate and the inflation rate. Each of the determinants has both a negative and a positive impact. The unemployment rate has the greatest impact on the profitability level in the following subindustries - 492, 504 (ROA), 494, 503, 512 (ROE), 492, 494, 502, 503 (ROS). In the case of subindustry 502, the impact is positive, in the remaining cases the impacts are negative. The negative effects are justified by the decrease of the unemployment rate from 7.2 to $4.2 \%$ during the observed period. As a result of the decline, the number of employees with a salary higher than unemployment benefits got higher. Consequently, the people's disposable income increased so they could demand for more production of the given subindustries. The influence of economic development can be found in subindustries 502, 503 (ROA), 504 (ROE), 491, 493, 504, 512 (ROS). In the case of subindustry 512 , the impact is negative, in the remaining cases the impacts are positive. The development of the Romanian economy was very strong throughout almost the entire observed period; in 2010, a decrease occurred of less than $4 \%$ as the consequence of the financial crisis in 2008/2009, when the Romanian government had to apply for an international loan to strengthen the credit market. In the following years, the year-on-year was respectable and in 2017 , it even exceeded $7 \%$. The economy was prospering and businesses and households could demand for more products and were prospering, too. The reference interest rate affected the profitability of subindustries 491, 522 (ROA), 491, 502, 522 (ROE) and 511 (ROS). For subindustries 491, 522 and 511 this impact is positive, for the remaining subindustries the effect is negative. The development of this rate is similar to the Polish and Hungarian rates. This rate decreased from 6.3 to $1.8 \%$ during the period considered. This decrease had a negative impact meaning very low costs of a debt financing acquisition, based on which the additional assets could be bought and equity, sales, production and profits could increase. On the other hand, the interest rate was high in the first half of the period, which had a positive impact due to e.g. the fact that companies borrowed finances at higher costs and could still increase their profitability. The profitability level of subindustries 511, 512, 521 (ROA), 511 (ROE) and 532 (ROS) is affected by the inflation rate. This rate averaged $2.7 \%$, which is the most out of the monitored economies. Such a high value could reduce the real expression of interest rates, which could thus become lower and companies gained a room for debt financing; they could acquire additional assets, increase their equity, extend the production thus increase their profit. Negative impacts are difficult to justify.

A brief summary should be provided at the end of this section. In this part, only the largest impacts of determinants on selected profitability indicators in individual subindustries were discussed. Out of the one hundred and eighty-seven cases, the impact of the reference interest rate dominated in ninety cases. Most of these effects were negative meaning that a decrease of the rate would allow the lower debt financing costs; as the consequence of it, companies' assets and equity would increase, thus production, sales and profits would increase as well. In some economies, these interest rates were high at the beginning of the period under review but fell during this period, thus fulfilling our assumption. Other economies had these interest rates of almost $0 \%$ throughout the period under review, thus also fulfilling our assumption. 


\section{Conclusions}

This research dealt with corporate profitability and its determinants. The analysed companies came from the transportation and storage industry and involved eight selected economies of Central and Eastern Europe. Namely, Czech Republic, Slovakia, Poland, Hungary, Austria, Bulgaria, Slovenia and Romania were considered. The business profitability of the selected industry was analysed involving fifteen subindustries and a total of 25,242 companies. The data covered the period 2010-2018. This period was chosen with regard to the time series located in the Orbis database. Unfortunately, a longer time series was not available. If we look at the economic development since 2018, when the world was hit by the covid pandemic, it can be assumed that the results could differ with the data for the period 2019-2021. However, due to the fact that all selected determinants come from the external environment of the company, the results of this research do not lose their value despite the change in the economic environment, as these are the main macroeconomic indicators that always affect business activities.

The sector is considered one of the most important sectors in Europe and therefore in the world, as it touches our daily activities - tourist transport, transport to work, storage of goods or food. Given its importance, the sector deserves an attention even though, according to the statistics, the sector accounts for only around 5\% of the European Union's GDP.

The aim of the research was to find out whether selected factors influence the company's profitability or not. Specifically, there are six selected macroeconomic factors - the rate of GDP growth, the inflation rate, the reference interest rate, the unemployment rate, gross fixed capital formation and the exchange rate against the euro.

Given that eight economies, over 25,000 companies and the impact of six determinants were analysed, it is clear that there is a significant number of results. The previous part described in detail the most significant impacts of determinants in the given subindustries and individual economies with regard to three selected profitability indicators. One main conclusion emerged out of these analyses. The level of corporate profitability of the transportation and storage industry is primarily influenced by the level of the reference interest rate of the given economies. The negative influence dominated meaning that when interest rates fell, profitability should have increased; companies could take advantage of cheaper debt financing, which could generate additional profitability by buying assets and investing in equity. The resulting impact is not unexpected, as in the Czech Republic, Slovakia, Austria, Slovenia and Bulgaria, the values of key interest rates were very low, balancing around the zero for most of the period under review. Although interest rates were higher in Poland, Romania and Hungary at the beginning of the period under review, they fell sharply during the period under review making foreign sources of financing more attractive.

If we take a brief look at the results from the perspective of individual economies, the impact of the reference interest rate was most significant for Slovak, Polish, Hungarian, Austrian, Slovenian and Bulgarian companies. The profitability level of Czech companies was mostly affected by the inflation rate and the unemployment rate. The dominant positive effect 
of the inflation rate can be justified by the fact that in the Czech Republic, the average inflation rate was $1.6 \%$ during the period under review, which may have reduced the real expression of interest rates, which may have become lower and companies thus gained a room for debt financing; this way they could acquire additional assets and increase the equity, extend the production and consequently make higher profit. The predominant negative impact of the unemployment rate is justified by the decrease in this rate from 7.3 to $2.2 \%$. During the reference period. The increase in the employed population meant an increase in the disposable income that could be spent on products in the industry. The profitability level of Romanian companies was mostly affected by the unemployment rate, which had a predominantly negative impact. This impact is related to the decrease in the unemployment rate from 7.2 to $4.2 \%$ during the period under review. As a result of decline in unemployment, the number of employees with a salary higher than social unemployment benefits is increased. Consequently, a disposable income of population increased thus people were able to demand for more products and services of the sector.

\section{Acknowledgment}

This work was supported by the Student Grant Foundation of the Silesian University in Opava, Grant No. SGF/8/2020, which was realized within the EU OPSRE project entitled "Improving the quality of the internal grant scheme of the Silesian University in Opava", reg. number: CZ.02.2.69/0.0/0.0/19_073/0016951.

\section{References}

AKOTEY, J. O., F. G. SACKEY and L. AMOAH (2013). The financial performance of life insurance companies in Ghana. Journal of Risk Finance, Vol. 14, No. 3, pp. 286-302. DOI: https://doi.org/10.1108/JRF-11-2012-0081

ALBERTAZZI, U. and L. GAMBACORTA (2009). Bank profitability and the business cycle. Journal of Finance Stability, Vol. 5, No. 4, pp. 393-409.

ALIAGA-DIAZ, R. and M. P. OLIVERO (2010). The Cyclicality of Price-Cost Margins in Banking: An Empirical Analysis of its Determinants. Economic Inquiry, Vol. 49 No. 1, pp. 26-46. DOI: https://doi.org/10.1111/j.1465-7295.2010.00327.x

ALMEIDA, F. and J. A. DIVINO (2015). Determinants of the banking spread in the Brazilian economy: The role of micro and macroeconomic factors. International Review of Economics and Finance, Vol. 40, pp. 29-39. DOI: 10.1016/j.iref.2015.02.003

ARELLANO, M. and S. BOND (1991). Some Tests of Specification for Panel Data: Monte Carlo Evidence and an Application to Employment Equations. Review of Economic Studies, Vol. 58, No. 2, pp. 277-297. DOI: https://doi.org/10.2307/2297968

AREALLANO, M. and O. BOVER (1995). Another look at the instrumental variable estimation of error-components models. Journal of Econometrics, Vol. 68, pp. 29-51. DOI: https://doi.org/10.1016/0304-4076(94)01642-D 
ATHANASOGLOU, P. P., S. N. BRISSIMIS and M. D. DELIS (2008). Bank-specific, industryspecific and macroeconomic determinants of bank profitability. Journal of International Financial Markets, Institutions and Money, Vol. 18, No. 2, pp. 121-136. DOI: https://doi.org/ 10.1016/j.intfin.2006.07.001

BASHIR, A. H. (2003). Determinants of profitability in Islamic banks: Some evidence from the Middle East. Islamic Economic Studies, Vol. 11, No. 1, pp. 31-57.

BIKKER, J. and H. HU (2002). Cyclical patterns in profits, provisioning and lending of banks and procyclicality of the new Basel capital requirements. Banca Nazionale del Lavoro Quarterly Review, Vol. 55, No. 221, pp. 143-175.

BLUNDELL, R. and S. BOND (1998). Initial conditions and moment restrictions in dynamic panel data models. Journal of Econometrics, Vol. 87, No. 1, pp. 115-143. DOI: https://doi.org/ 10.1016/S0304-4076(98)00009-8

BOURKE, P. (1989). Concentration and other determinants of bank profitability in Europe, North America and Australia. Journal of Banking and Finance, Vol. 13, pp. 65-79. DOI: https://doi.org/10.1016/0378-4266(89)90020-4

CHOUIKH, A. and Y. BLAGUI (2017). The Determinants of Bank Performance: The Case of Tunisian Listed Banks. Journal of Finance and Accounting, Vol. 5, No. 2, pp. 53-60. DOI: 10.12691/jfa-5-2-4

CLAESSENS, S., A. DEMIRGÜC-KUNT and H. HUIZINGA (1998). How Does Foreign Entry Affect the Domestic Banking Market? Policy Research Working Paper No. 1918.

ĆURAK, M., K. POPOSKI and S. PEPUR (2012). Profitability Determinants of the Macedonian Banking Sector in Changing Environment. Procedia - Social and Behavioral Sciences, Vol. 44, pp. 406-416. DOI: https://doi.org/10.1016/j.sbspro.2012.05.045

DEMIRGÜC-KUNT, A. and H. HUIZINGA (1998). Determinants of Commercial Bank Interest Margins and Profitability: Some International Evidence. The World Bank Economic Review, Vol. 13, No. 2, pp. 379-408. DOI: 10.1093/wber/13.2.379

DIETRICH, A. and G. WANZENRIED (2011). Determinants of bank profitability before and during the crisis: Evidence from Switzerland. Journal of International Financial Markets, Institutions and Money, Vol. 21, pp. 307-327. DOI: http://dx.doi.org/10.2139/ssrn.1370245

DIETRICH, A. and G. WANZENRIED (2014). The determinants of commercial banking profitability in low-, middle-, and high-income countries. The Quarterly Review of Economics and Finance, Vol. 54, pp. 337-354. DOI: https://doi.org/10.1016/j.qref.2014.03.001

DJALILOV, K. and J. PIESSE (2016). Determinants of bank profitability in transition countries: What matters most? Research in International Business and Finance, Vol. 38, pp. 69-82. DOI: https://doi.org/10.1016/j.ribaf.2016.03.015

FLAMINI, V., C. MCDONALD and L. SCHUMACHER (2009). The Determinants of Commercial Bank Profitability in Sub-Saharan Africa. IMF Working paper No. 15. DOI: 10.5089/ 9781451871623.001

GAGANIS, CH., I. HASAN and F. PASIOURAS (2013). Efficiency and Stock Returns: Evidence from the Insurance Industry. Journal of Productivity Analysis, Vol. 40, pp. 429-442. DOI: 10.1007/s11123-013-0347-X

GODDARD, J., P. MOLYNEUX and J. O. S. WILSON (2004). The profitability of European banks: a cross-sectional and dynamic panel analysis. The Manchester School, Vol. 72, No. 3, pp. 363-381. DOI: 10.1111/j.1467-9957.2004.00397.x 
JAGANNATHAN, R., G. SKOULAKIS and Z. WANG (2002). Generalized Method of Moments: Applications in Finance. Journal of Business and Economic Statistics, Vol. 20. No. 4, pp. 470-481. DOI: 10.1198/073500102288618612

KILLINS, R. N. (2020). Firm-specific, industry-specific and macroeconomic factors of life insurers' profitability: Evidence from Canada. North American Journal of Economics and Finance, Vol. 51. DOI: https://doi.org/10.1016/j.najef.2019.101068

KOŠAK, M. and M. ČOK (2013). Ownership Structure and Profitability of the Banking Sector: The Evidence from the SEE-6 Region. Proceedings of Rijeka Faculty of Economics, Journal of Economics and Business, Vol. 26, No. 1, pp. 93-112.

LE, T. D. and T. NGO (2020). The determinants of bank profitability: A cross-country analysis. Central Bank Review, Vol. 20, pp. 65-73. DOI: https://doi.org/10.1016/j.cbrev.2020.04.001

MARTINS, A. M., A. P. SERRA and S. STEVENSON (2019). Determinants of real estate bank profitability. Research in International Business and Finance, Vol. 49, pp. 282-300. DOI: https://doi.org/10.1016/j.ribaf.2019.04.004

MIRZAEI, A., M. TOMOE and G. LIU (2013). Does market structure matter on banks' profitability and stability? Emerging vs. advanced economies. Journal of Banking and Finance, Vol. 37, pp. 2920-2937. DOI: https://doi.org/10.1016/j.jbankfin.2013.04.031

MOLYNEUX, P. and J. THORNTON (1992). Determinants of European bank profitability: A note. Journal of Banking and Finance, Vol. 16, No. 6, pp. 1173-1178. DOI: https://doi.org/ 10.1016/0378-4266(92)90065-8

PERVAN, M., I. PERVAN and A. GUADAGNINO (2010). Market Structure and Profitability of Croatian Commercial Banks. The Business Review, Vol. 20, No. 1, pp. 209-216.

PRŮCHA, I. R. (2014). Instrumental Variables/Method of Moments Estimation. In: FISHER, M. M. \& P. NIJKAMP (Rd.), Handbook of Regional Science. Heidelberg: Springer, pp. 1597-1617. ISBN 978-3-642-23429-3.

ROODMAN, D. (2009). How to do xtabond2: An introduction to difference and system GMM in Stata. The Stata Journal, Vol. 9, No. 1, pp. 86-136. DOI: https://doi.org/10.1177/ $1536867 X 0900900106$

SAONA, P. (2016). Intra- and Extra-bank Determinants of Latin American Banks'Profitability. International Review of Economics and Finance, Vol. 45, pp. 197-214. DOI: https://doi.org/ 10.1016/j.iref.2016.06.004

SUFIAN, F. and R. R. CHONG (2008). Determinants of Bank Profitability in a Developing Economy: Empirical Evidence from the Philippines. Asian Academy of Management Journal of Accounting and Finance, Vol. 4, No. 2, pp. 91-112.

TAN, Y. A. and Ch. FLOROS (2012). Bank profitability and inflation: The case of China. Journal of Economic Studies, Vol. 39, No. 6, pp. 675-696. DOI: 10.1108/01443581211274610

ULLAH, S. et al. (2018). Dealing with Endogeneity Bias: The Generalized Methods of Moments (GMM) for panel data. Industrial Marketing Management, Vol. 71, pp. 69-78. DOI: https://doi.org/10.1016/j.indmarman.2017.11.010

VERA-GILCES, P. et al. (2020). A look inside banking profitability: Evidence from a dollarized emerging country. The Quarterly Review of Economics and Finance, Vol. 75, pp. 147-166. DOI: https://doi.org/10.1016/j.qref.2019.05.002 
ZUIDBERG, J. (2017). Exploring the determinants for airport profitability: Traffic characteristics, low-cost carriers, seasonality and cost efficiency. Transportation Research Part A, Vol. 101, pp. 61-72. DOI: https://doi.org/10.1016/j.tra.2017.04.016

\section{Contact address}

doc. Ing. Petra Růčková, Ph.D.

Associate Professor, Silesian University in Opava, School of Business Administration in Karvina, Department of Finance and Accounting

Univerzitní náměstí 1934/3

73340 Karviná, Czech Republic

(ruckova@opf.slu.cz)

\section{Ing. Nicole Škuláňová (corresponding author)}

PhD. Student, Silesian University in Opava, School of Business Administration in Karvina, Department of Finance and Accounting

Univerzitní náměstí 1934/3

73340 Karviná, Czech Republic

(skulanova@opf.slu.cz) 